\title{
O SUPREMO TRIBUNAL FEDERAL E A MUDANÇA CONSTITUCIONAL
}

\section{Fabiana Luci de Oliveira ${ }_{(1)}$ (D)}

E-mail: fabianaluci@ufscar.br

\section{Diego Werneck Arguelhes}

E-mail: diegowa@insper.edu.br

(1) Universidade Federal de São Carlos (UFSCAR), São Carlos - SP, Brasil. Bolsista Produtividade CNPq.

(2) Instituto de Ensino e Pesquisa (Insper), São Paulo - SP, Brasil.

DOI: $10.1590 / 3610506 / 2020$

\section{Introdução}

O presente artigo analisa as reaçôes de atores políticos e da sociedade civil organizada a processos de mudança constitucional, expressas na judicialização, perante o Supremo Tribunal Federal, de discussóes sobre emendas à Constituição de 1988. Os resultados apontam para a centralidade do controle de constitucionalidade de emendas na política constitucional brasileira, por meio de açóes diretas de inconstitucionalidade (ADIs), com destaque para a judicialização promovida por alguns grupos de interesses organizados. $\mathrm{O}$ artigo analisa como esses atores se mobilizaram para questionar emendas constitucionais no STF, bem como os resultados que têm obtido nessas disputas mais amplas sobre qual é (e quem decide) o núcleo imutável da Constituição.

Artigo recebido em: 22/08/2019

Aprovado em: 11/03/2020
A questão do controle judicial da constitucionalidade de emendas, no caso brasileiro, vem sendo objeto de diversos trabalhos acadêmicos, sobretudo no campo do Direito Constitucional (Mendes, 2005; Mohallem, 2011; Roznai e Kreuz, 2018; Pereira, 2016; Salgado e Chagas, 2019). Entretanto, essa produção se concentra na discussão de casos específicos de controle judicial de emendas pelo STF, ou na configuração normativa deste poder no ordenamento jurídico brasileiro. Ainda que importantes para uma discussão abrangente do fenômeno no caso brasileiro, estes trabalhos são insuficientes para compreender como o poder de controlar emendas tem sido acionado e utilizado na prática decisória do tribunal, com efeitos potenciais no comportamento de atores políticos e sociais.

Por sua vez, abrangendo todas as Açóes Diretas de Inconstitucionalidade ajuizadas contra emendas à Constituição, Glezer (2013) procura analisar quais atores e temas se destacam, além de qual vinha sendo a resposta do STF a essa judicialização. O presente 
trabalho segue essa mesma linha. Utilizamos um banco de dados atualizado até 2018, e uma categorização e interpretação próprias, para analisar quais têm sido as disputas políticas em torno das mudanças na Constituição e como o STF tem arbitrado o confronto entre as forças políticas em disputa. A categorização utilizada aqui baseia-se nas pesquisas de Vianna, Burgos e Salles (2007) e Oliveira (2016) sobre a judicialização da política a partir de ADIs, adaptada em diálogo com os trabalhos de Souza (2008), Lassance (2016) e Arantes e Couto (2019), que analisaram e classificaram o conteúdo das emendas à Constituição brasileira.

A partir da análise de conteúdo das petiçóes e decisóes (quando existentes) em um total de $115 \mathrm{ADIs}$ que arguiram a inconstitucionalidade de emendas à Constituição, buscamos: 1) identificar as emendas que provocaram contestação, comparando os temas das que foram e das que não foram arguidas de inconstitucionalidade; 2) identificar e caracterizar os atores que buscaram o STF para impedir, mitigar ou alterar o conteúdo da mudança constitucional, identificando os argumentos em torno dos quais essa contestação foi construída; e 3) analisar o posicionamento do STF, ou seja, como o tribunal respondeu ao questionamento: se decidiu de forma favorável ou desfavorável ao pedido de interferência no processo de mudança constitucional.

\section{A judicializaçáo da mudança constitucional no Brasil}

A Constituição de 1988 parece criar condições ideais para a judicialização de processos de mudança constitucional, por dois conjuntos de razóes. $\mathrm{O}$ primeiro diz respeito aos incentivos que cria para a própria adoção de emendas constitucionais. De fato, nos últimos trinta anos, "a Constituiçáo de 1988 permaneceu em constante transformação e significativo crescimento" (Arantes e Couto, 2019, p. 14). Ao assumir um perfil detalhista e entrincheirar, em seu texto, uma série de temas e políticas públicas, a Constituição cria para sucessivos governos a "necessidade de modificar o ordenamento constitucional para poder implementar parte de suas plataformas de governo" (Arantes e Couto, 2006, p. 43). Recuperando Jack Knight (2001), Arantes e
Couto explicam essa escolha a partir do contexto de desconfiança entre as forças políticas que participaram do processo constituinte. Quando nenhum grupo tem hegemonia no processo, e existe incerteza quanto a quais forças políticas serão maioria no futuro, há incentivos para a constitucionalização de dispositivos de políticas públicas, imposição de critérios mais rigorosos de emendamento constitucional e ampliação do escopo do controle judicial de constitucionalidade de leis e demais atos normativos (Arantes e Couto, 2008, p. 43).

As mais de cem emendas ao texto original, porém, pouco transformaram o sistema político e a lista de direitos, que poderiam ser considerados o "núcleo" da Constituição (Vieira e Barbosa, 2018). Em uma série de trabalhos sobre mudança constitucional no Brasil pós 1988, Arantes e Couto observam que o alto grau de emendamento da Constituição tende a se concentrar não nos dispositivos constitucionais que consagrariam as "regras do jogo" - dispositivos de polity, as estruturas básicas do funcionamento do estado e do processo político -, mas sim no que chamam de dispositivos de policy: políticas públicas específicas que, em princípio, variariam de governo para governo (Arantes e Couto, 2019, pp. 22-23). Apresentando uma predominância de dispositivos de policy $(30,7 \%)$, bem acima do que os autores encontram em diversas constituiçóes estrangeiras, essa constituição "extensa e detalhada (...) enredou geraçôes futuras em compromissos pontuais e conjunturais que, para serem revistos, necessitam de maiorias mais amplas do que as democraticamente eleitas" (Arantes e Couto, 2019, pp. 28-29).

Se o primeiro conjunto de razóes para a judicialização da mudança constitucional diz respeito aos incentivos à adoção de emendas, o segundo se refere aos mecanismos que existem para controlar a mudança no texto constitucional. Embora não traga previsão explícita quanto ao controle de constitucionalidade de emendas, o art. 60, $\$ 4^{\circ}$, da Constituição Federal, proíbe que o Congresso sequer delibere sobre propostas de emendas que "tendam a abolir" as chamadas "cláusulas pétreas". Esse dispositivo vem sendo interpretado pelo STF como uma autorização para o controle de constitucionalidade de emendas. ${ }^{1}$ 
Antes da Constituição de 1988, o tribunal já havia reconhecido a possibilidade de controle judicial de emendas em sede de Mandados de Segurança (MS) impetrados por parlamentares. Segundo o STF, parlamentares teriam um direito individual ao cumprimento das regras constitucionais sobre o processo legislativo, incluindo a proibiçáo de deliberação sobre emendas constitucionais que tenderiam a abolir cláusulas pétreas. ${ }^{2}$ Essa posição jurisprudencial foi mantida após a transição, mesmo depois de a possibilidade de um controle judicial preventivo de constitucionalidade ter sido rejeitada na constituinte de 1987/88 (Süssekind, 2014).

Para além de MS de parlamentares, a primeira vez que o Tribunal se manifestou sobre o controle (abstrato) de constitucionalidade de emendas foi em abril de 1991, no julgamento da Açáo Direta de Inconstitucionalidade (ADI) 466, autuada em 20 de março de 1991. Nessa ação, o PSB questionava a constitucionalidade da proposta de Emenda à Constituiçấo n. 1-B, de autoria do entâo deputado Amaral Neto (PDS/RJ, hoje PP), que visava instituir a pena de morte, a partir da realização de um plebiscito. O PSB argumentava que a proposta tenderia a abolir direitos e garantias individuais, entre os quais o direito à vida.

O Supremo não conheceu da ação, alegando a impossibilidade de fiscalizaçáo abstrata preventiva de proposiçốes normativas. Não obstante, os ministros reconheceram que, uma vez aprovada e promulgada a Emenda, ela seria, sim, passível de controle judicial, considerando a existência de um "núcleo temático intangível" que a Constituição teria tornado expressamente imune a alteraçôes. Lê-se na ementa dessa ADI:

A impossibilidade jurídica de controle abstrato preventivo de meras propostas de emenda não obsta a sua fiscalização em tese quando transformadas em emendas à Constituição. Estas - que não são normas constitucionais originárias - não estão excluídas, por isso mesmo, do âmbito do controle sucessivo ou repressivo de constitucionalidade. O Congresso Nacional, no exercício de sua atividade constituinte derivada e no desempenho de sua função reformadora, está juridicamente subordinado à decisão do poder constituinte originário que, a par de restriçôes de ordem circunstancial, inibitórias do poder reformador $\left(\mathrm{CF}\right.$, art. $\left.60, \$ 1^{\circ}\right)$, identificou, em nosso sistema constitucional, um núcleo temático intangível e imune à ação revisora da instituição parlamentar. Às limitaçóes materiais explícitas, definidas no $\$ 4^{\circ}$ do art. 60 da Constituição da República, incidem diretamente sobre o poder de reforma conferido ao Poder Legislativo da União, inibindo-lhe o exercício nos pontos ali discriminados. A irreformabilidade desse núcleo temático, acaso desrespeitada, pode legitimar o controle normativo abstrato, e mesmo a fiscalização jurisdicional concreta, de constitucionalidade. (EMENTA, ADI 466, 03.abr.1991, Relator Min. Celso de Mello)

O modelo institucional brasileiro, portanto, é o de uma Constituição extensa, detalhada e policy-oriented, com previsão aberta de "cláusulas pétreas", que o STF toma como base no controle judicial de emendas que ameacem esse núcleo imutável. Esse arranjo levou o ministro Sepúlveda Pertence a prever que seria praticamente inevitável que a cada emenda constitucional se seguisse ADI, movida por forças vencidas no processo político, para questionar violaçóes aos limites formais e materiais ao poder de reforma constitucional (Pertence, 2003).

Essa previsão se concretizou em parte. No período de 6 de outubro de 1988, data de ingresso da primeira ADI, até 1 de agosto de 2018, data da última ação catalogada na base de dados aqui utilizada, haviam sido distribuídas no STF 5.985 açôes. Destas, 115 questionavam emendas à Constituiçăo de 1988, o que corresponde a $2 \%$ do total de ADIs autuadas no período. Apenas 35 das emendas aprovadas foram objeto de arguição de inconstitucionalidade por meio de ADIs. ${ }^{3}$ Se considerarmos as 105 emendas aprovadas até 2018 (99 emendas constitucionais e 6 emendas constitucionais de revisão), observamos que uma a cada três emendas constitucionais teve sua constitucionalidade contestada ${ }^{4}$. Essas contestaçôes correspondem ao que, para os fins deste trabalho, consideramos 123 diferentes questionamentos (pedidos), tendo em vista que há um pequeno conjunto de 
ADIs que têm como objeto a inconstitucionalidade de mais de uma emenda constitucional.

A EC 2/1992 foi a primeira a ser contestada via controle abstrato no STF, na ADI 829, autuada em 15 de janeiro de 1993 . A ação questionava a alteração da data de realização do plebiscito nacional sobre forma e sistema de governo. A emenda antecipava a data de 7 de setembro de 1993 para 21 de abril do mesmo ano. Outras duas açóes (ADI 830 e ADI 833) impugnaram a mesma emenda, alegando ofensa à separação de poderes. No julgamento dessas ações, o tribunal reafirmou, unanimemente, sua competência para examinar, em controle concreto ou abstrato, a constitucionalidade de emendas à Constituição. ${ }^{5}$

Após essas primeiras contestaçóes em controle abstrato, levou algum tempo até o Supremo utilizar de fato seu poder de controle. A primeira emenda a ter dispositivos declarados inconstitucionais foi a EC 3/1993, que instituía o IPMF, nas ADI 926 e ADI 939. Proposta por governadores de cinco estados (PR, SC, TO, MS e MT), em 28 de agosto de 1993, a ADI 926 teve liminar deferida por unanimidade, em 1 de setembro de 1993, com o Tribunal reconhecendo a violação à imunidade tributária recíproca das entidades estatais como ofensa ao princípio federativo. ${ }^{6}$ A ADI 939, proposta pela Confederação Nacional dos Trabalhadores no Comércio (CNTC), alegava violação ao princípio da anterioridade e da vedação à bitributação, entre outras inconstitucionalidades. A liminar foi deferida em 15 de setembro de 1993 , e o mérito foi julgado parcialmente procedente em 15 de dezembro de $1993 .^{7}$

Desde então, o STF deferiu (total ou parcialmente) um quinto dos pedidos de inconstitucionalidade de ECs. Tal frequência de declaração de inconstitucionalidade pode ser considerada relativamente alta. Na próxima seção, detalharemos essas açóes quanto às emendas a que se referem.

\section{Padróes de judicialização de Emendas à Constituição}

\section{Quais ECs foram judicializadas?}

As 105 emendas à Constituição geraram graus variados de controvérsia jurídica; apenas 35 delas foram questionadas junto ao STF por ADIs. Dessas, as mais questionadas por via de $\mathrm{ADI}$ foram as duas que tratavam de reformas previdenciárias (EC 41/2003 e EC 20/1998) e a que dispunha sobre reforma do Judiciário (EC 45/2004). Essas três ECs respondem por $44 \%$ dos pedidos de impugnaçáo de emendas à

Gráfico 1. Número de ADIs, de acordo com EC

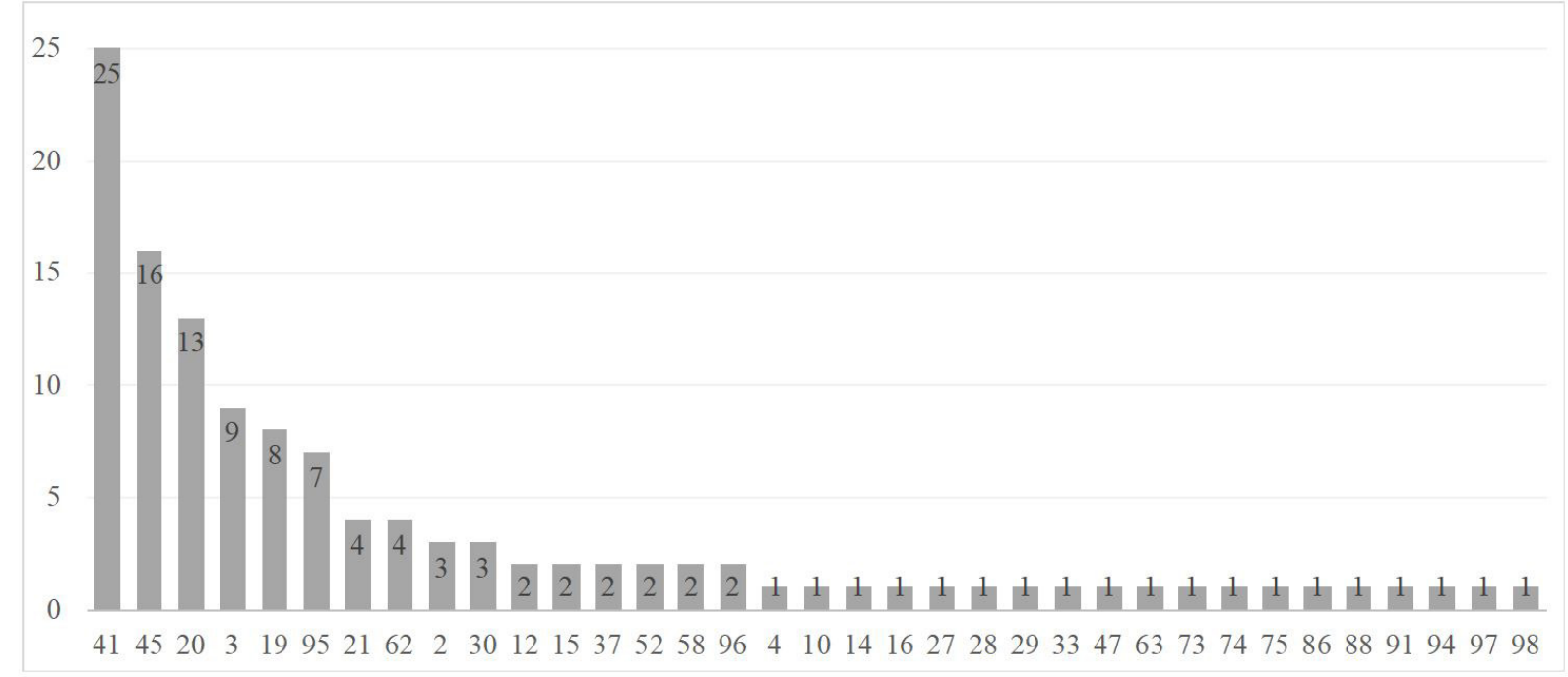

Base: 123 pedidos; Fonte: Pesquisa Fapesp 
Constituiçăo (Gráfico 1). A EC 3/1993 vem em quarto lugar, com nove pedidos de inconstitucionalidade, referentes aos dispositivos que instituíram o IPMF, à Ação Declaratória de Constitucionalidade de lei ou ato normativo federal (ADC) e à desvinculação de receitas tributárias. Em quinto, encontramos a EC 19/1998, referente à reforma administrativa do governo Fernando Henrique Cardoso. Entre suas principais medidas, essa emenda extinguiu o chamado "regime jurídico único"; modificou as regras de remuneração e estabilidade dos servidores; e adotou o controle das despesas e finanças públicas. Das emendas mais recentes, a campeã de questionamentos é a EC 95/2016, que limita por vinte anos os gastos públicos, instituindo o novo regime fiscal ou o teto dos gastos. Até agosto de 2018, haviam sido propostas sete ADIs arguindo a sua inconstitucionalidade.

Para categorizar as ECs em temas predominantes, adaptamos as classificaçóes temáticas propostas por Vianna, Burgos e Salles (2007), Souza (2008), Lassance (2016) e Oliveira (2016). Pode-se observar que as mudanças mais frequentes foram relativas à política fiscal e à política tributária (Tabela 1). Foram classificadas nesse tema as emendas que trataram da criação do Fundo Social de Emergência (FSE), de sua conversão no mecanismo de Desvinculação de Receitas da União (DRU), da instituição do Fundo de Manutençáo e Desenvolvimento do Ensino Fundamental e de Valorizaçấo do Magistério (FUNDEF), além de emendas que criaram ou regulamentaram impostos (como CIDE, IPTU,
IPMF, CPMF, etc.) ou trataram de imunidade tributária e precatórios. O tema corresponde a 31\% das emendas promulgadas até 2018. É a segunda área mais disputada no STF; $45 \%$ das ECs que dispunham sobre política fiscal e tributária foram judicializadas por meio de ADIs.

$\mathrm{O}$ segundo assunto com maior incidência em reformas está ligado à agenda de direitos e sociedade civil, incluindo, por exemplo, a proibiçáo do trabalho de menores; o salário licença-maternidade; o direito de ação do trabalhador rural; a instituição do Plano Nacional de Cultura; e as práticas desportivas envolvendo animais, entre outros aspectos. No período, dezenove emendas aprovadas tratavam desse assunto ( $18 \%$ do total). No entanto, essa é a segunda área menos controversa, com apenas três emendas contestadas (EC 20/1998, EC 28/2000 e EC 96/2017).

Os temas relativos aos servidores públicos (estabilidade; regime de previdência; remuneração etc.) e ao sistema político-eleitoral (permanência em cargo de quem concorre à reeleiçáo; vigência de lei que altera eleiçóes; janela partidária etc.) vêm na sequência, ocupando o terceiro lugar em termos de incidência de reforma, com quinze emendas cada um. São, proporcionalmente, os assuntos mais controversos. Quase metade das emendas relativas a cada um deles foi judicializada.

A quarta temática mais frequente nas emendas aprovadas pelo Congresso é a administração da Justiça. Ela inclui questôes como a reforma do Judiciário; a composição do Conselho Nacional

Tabela 1.

Temática das ECs, de acordo com o total de ECs promulgadas e o total de ECs judicializadas

\begin{tabular}{|c|c|c|c|c|}
\hline \multirow{2}{*}{ Tema EC } & \multicolumn{2}{|c|}{ Total EC } & \multicolumn{2}{|c|}{ EC contestada no STF } \\
\hline & $\mathbf{N}$ & $\%$ & $\mathbf{N}$ & $\%$ \\
\hline Política fiscal e tributária & 33 & $31 \%$ & 15 & $45 \%$ \\
\hline Direitos e sociedade civil & 19 & $18 \%$ & 3 & $16 \%$ \\
\hline Servidor público & 15 & $14 \%$ & 7 & $47 \%$ \\
\hline Sistema Político-eleitoral & 15 & $14 \%$ & 7 & $47 \%$ \\
\hline Administração da Justiça & 10 & $10 \%$ & 4 & $40 \%$ \\
\hline Política Econômica & 9 & $9 \%$ & 0 & $0 \%$ \\
\hline Administração Pública & 6 & $6 \%$ & 1 & $17 \%$ \\
\hline Total & 105 & $100 \%$ & 35 & $33 \%$ \\
\hline
\end{tabular}

Obs.: ECs 3 e 20 estáo classificadas, cada uma, em dois temas, devido à diversidade de dispositivos. Fonte: Pesquisa Fapesp 
de Justiça (CNJ); a criação de TRFs e mudanças nas competências e instrumentos processuais do Supremo Tribunal Federal, como a criação da Ação Declaratória de Constitucionalidade, entre outros. Esse foi o terceiro tema com mais emendas judicializadas: quatro das dez ECs sobre administração da Justiça foram impugnadas no STF.

As mudanças na política econômica, que totalizam nove emendas constitucionais, não provocaram nenhuma impugnação. Esse aspecto chama atenção, sobretudo em decorrência das emendas constitucionais 5, 6, 8 e 9 (relativas ao gás canalizado, às telecomunicaçóes, à indústria de petróleo e ao gás natural, respectivamente), promulgadas em 1995, que pavimentaram o caminho das privatizações. $\mathrm{O}$ fato dessas emendas não terem provocado nenhum questionamento no STF - por parte de qualquer ator legitimado, incluindo atores não-estatais - pode sinalizar que sua aprovação foi resultado de um processo eficaz de negociação no âmbito do Congresso e da sociedade civil organizada. A plausibilidade dessa hipótese é reforçada se considerarmos que, como apontam estudos anteriores, os incentivos dos atores políticos para a judicialização vão muito além da perspectiva de uma vitória judicial (Taylor, 2007), podendo, inclusive, encorajar os próprios atores governistas a adotar estratégias judicializantes (Taylor e Da Ros, 2008). Assim, em temas tão centrais, visíveis e consequentes do processo político nacional, seria esperado que esses múltiplos incentivos estimulassem ainda mais a judicialização.

A Tabela 2 apresenta o objeto detalhado dos questionamentos e sua frequência relativa. A especificação dos temas dos objetos em disputa em cada emenda questionadas permite observar que os interesses da magistratura e das demais carreiras públicas da Justiça são os mais frequentes ${ }^{8}$. Em especial, as alteraçôes no regime de aposentadoria dos magistrados foram objeto de $11 \%$ dos questionamentos. O segundo objeto mais frequente foi o regime de previdência dos servidores públicos em geral, seguido da contribuição previdenciária dos servidores inativos e da estrutura de remuneração das carreiras públicas. Esses resultados e suas possíveis implicaçóes serão objeto de discussão na próxima seção.
Tabela 2.

Detalhamento do objeto da EC questionado na ADI, de acordo com o total de pedidos

\begin{tabular}{lc}
\hline \multicolumn{1}{c}{ Objeto } & $\%$ \\
\hline Aposentadoria de magistrados & $11 \%$ \\
\hline Regime de previdência servidor público) & $9 \%$ \\
\hline Contribuição previdenciária servidor inativo & $8 \%$ \\
\hline Remuneraçáo servidor público & $8 \%$ \\
\hline Competência da Justiça Trabalho & $7 \%$ \\
\hline Precatórios - regime de pagamento & $7 \%$ \\
\hline IPMF & $7 \%$ \\
\hline CPMF & $7 \%$ \\
\hline Novo Regime Fiscal & $6 \%$ \\
\hline Mudança de data plebiscito & $2 \%$ \\
\hline Eleiçóes - coligaçóes & $2 \%$ \\
\hline Estabilidade servidor público & $2 \%$ \\
\hline Competência da Justiça Federal & $2 \%$ \\
\hline Criação/desmembramento de municípios & $2 \%$ \\
\hline Autonomia funcional da Defensoria Pública & $2 \%$ \\
\hline Composição das câmaras municipais & $2 \%$ \\
\hline Práticas desportivas com animais & $2 \%$ \\
\hline Remuneração de magistrados & $2 \%$ \\
\hline Outros (objetos com apenas 1 questionamento cada) & $15 \%$ \\
\hline Base 123 pelidos; Fonte: Pesqusa Fapesp
\end{tabular}

Base: 123 pedidos; Fonte: Pesquisa Fapesp

Outros temas ligados aos interesses das carreiras públicas da justiça que se destacam são a remuneração de magistrados e a competência da Justiça do Trabalho e da Justiça Federal, além da autonomia da Defensoria Pública.

Entre os objetos com apenas um questionamento (agrupados na categoria "Outros"), destacam-se os relativos à política tributária ou fiscal, que incluem: redução do orçamento federal para ações e serviços públicos de saúde; CIDE; IPTU; FSE; DRU; FUNDEF; e imunidade tributária. Considerando a centralidade desses temas para o processo político nacional, a baixa frequência parece ser um resultado contra-intuitivo, que merece ser analisado e explicado em estudos futuros. Como indicado acima, é possível que a resposta esteja na solidez ou eficácia dos acordos políticos firmados no processo legislativo para a aprovação dessas emendas.

Em seguida, seis questionamentos envolvem objetos relativos ao mundo da Justiça ligados à carreira (férias dos magistrados e exercício de atividade político partidária 
por parte dos membros do Ministério Público) e à estrutura institucional (criação do CNJ e de Tribunais Regionais Federais - TRFs), além da composição do Conselho Nacional do Ministério Público (CNMP). Três questionamentos referem-se a direitos: direito de ação do trabalhador rural, proibição do trabalho de menores e salário licença-maternidade. Outros três objetos se relacionam ao tema eleitoral: permanência no cargo concorrendo à reeleição, vigência de lei que altera processo eleitoral e janela partidária.

Arantes e Couto (2006) desenvolveram a Metodologia de Análise Constitucional (MAC) para distinguir, no interior do texto constitucional, dois tipos de dispositivos constitucionais fundamentais, que chamam de polity (estruturas do regime; direitos individuais; direitos materiais orientados para o bem-estar e igualdade; regras do jogo político), e policy (veiculadores de políticas públicas, refletindo escolhas que, em princípio, variariam entre governos). A partir dessa metodologia, o texto original da Constituição foi classificado como contendo 1.627 dispositivos, dos quais 69,3\% são polity e 30,7\%, policy (Arantes e Couto, 2019, p. 24). Analisando as emendas constitucionais até 2018, os autores indicaram que a CF88 ficou $44 \%$ maior, com $80,5 \%$ do crescimento referindo-se a dispositivos de policy (p. 38).

Considerando a aplicaçáo dessa metodologia (MAC) às emendas ao texto original da Constituição aprovadas, é possível utilizá-la, também, para classificar os 123 questionamentos dessas mudanças constitucionais no STF. Classificando os questionamentos a partir da natureza - policy ou polity - da mudança (Gráfico 2) constitucional a que se referem, observamos que $78 \%$ das açóes questionaram só aspectos ligados a policy; $17 \%$ só aspectos ligados a polity; e 5\%, os dois tipos de dispositivos. Assim, de modo geral, os padrôes de contestação seguem a mesma tendência do perfil das emendas, no que se refere ao tipo de dispositivo, conforme a classificação de Arantes e Couto (2019). A disputa em torno da mudança constitucional nas ADIs se dá sobretudo no âmbito da policy.

O exame do tempo decorrido entre a promulgaçáo da emenda e o ingresso contra ela no STF mostra que um quarto das açóes ingressou no tribunal até dois meses depois da promulgação da EC, e metade delas até cinco meses depois da promulgação (Tabela 3). As

\section{Gráfico 2. Tipo de dispositivos questionados em cada ADI, de acordo com total de pedidos}

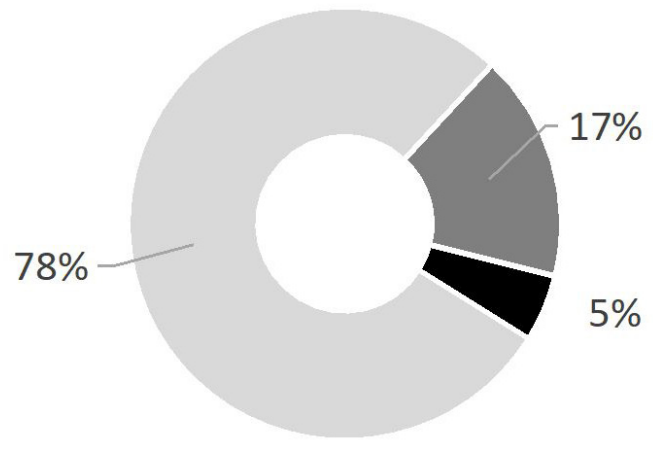

\section{Policy • Polity • Policy e Polity}

Base: 123 pedidos; Fonte: Pesquisa Fapesp

Tabela 3.

Tempo de ingresso da $\mathrm{ADI}$ em relaçáo à data de promulgaçáo EC

\begin{tabular}{lcc}
\hline & Dias & Anos \\
\hline Média & 773 & 2,1 \\
\hline Mediana & 172 & 0,5 \\
\hline Desvio Padráo & 1.211 & 3,3 \\
\hline Mínimo & $-21^{*}$ & 0 \\
\hline Máximo & 4.962 & 13,6 \\
\hline $25 \%$ & 60 & 0,2 \\
\hline $75 \%$ & 1.085 & 3,0 \\
\hline
\end{tabular}

Base: 123 pedidos; * ADI 3.367 contra EC 45/2004, questionada 21 dias antes da promulgaçáo dessa emenda; Fonte: Pesquisa Fapesp

arguições mais distantes, no tempo, da aprovação da emenda são as que questionam as reformas incrementais, como a reforma da previdência, em que a petição é voltada ao questionamento da emenda mais recente (EC 41/2003) e traz consigo o questionamento de emenda mais antiga (EC 20/1998).

A EC 15/1996, que dispôs sobre a criação, a incorporação, a fusão e o desmembramento de municípios, também teve questionamento tardio. Nesse caso, porém, não se questionou a emenda em si, mas sim a omissão legislativa diante desse dispositivo. O questionamento mais recente na base de dados (em 1 de agosto de 2018) também demorou consideravelmente em relação à data de promulgação: 
EC 45/2004, a chamada "Reforma do Judiciário", no aspecto em que veda aos membros do MP exercício de atividade político-partidária. ${ }^{9}$

Atores e interesses processuais: quem buscou barrar a mudança constitucional no STF?

Os profissionais das carreiras públicas da justiça, a partir de suas associaçóes, foram os atores que mais frequentemente buscaram limitar a mudança constitucional no Supremo (Gráfico 3). Um quarto dos pedidos das ADIs veio de associaçóes de magistrados, com a AMB e a ANAMATRA liderando a lista dos litigantes mais frequentes, tendo formulado 14 e 13 pedidos, respectivamente (Tabela 4). Somando as associações de magistrados às das demais carreiras públicas da justiça (Ministério Público e Defensoria Pública, e Delegados de Polícia), chega-se a um terço dos pedidos. Se considerarmos a OAB nesse grupo, chegamos a 38\% das açôes. Esses dados sugerem um diálogo restrito, entre participantes "iniciados" no sistema de Justiça.

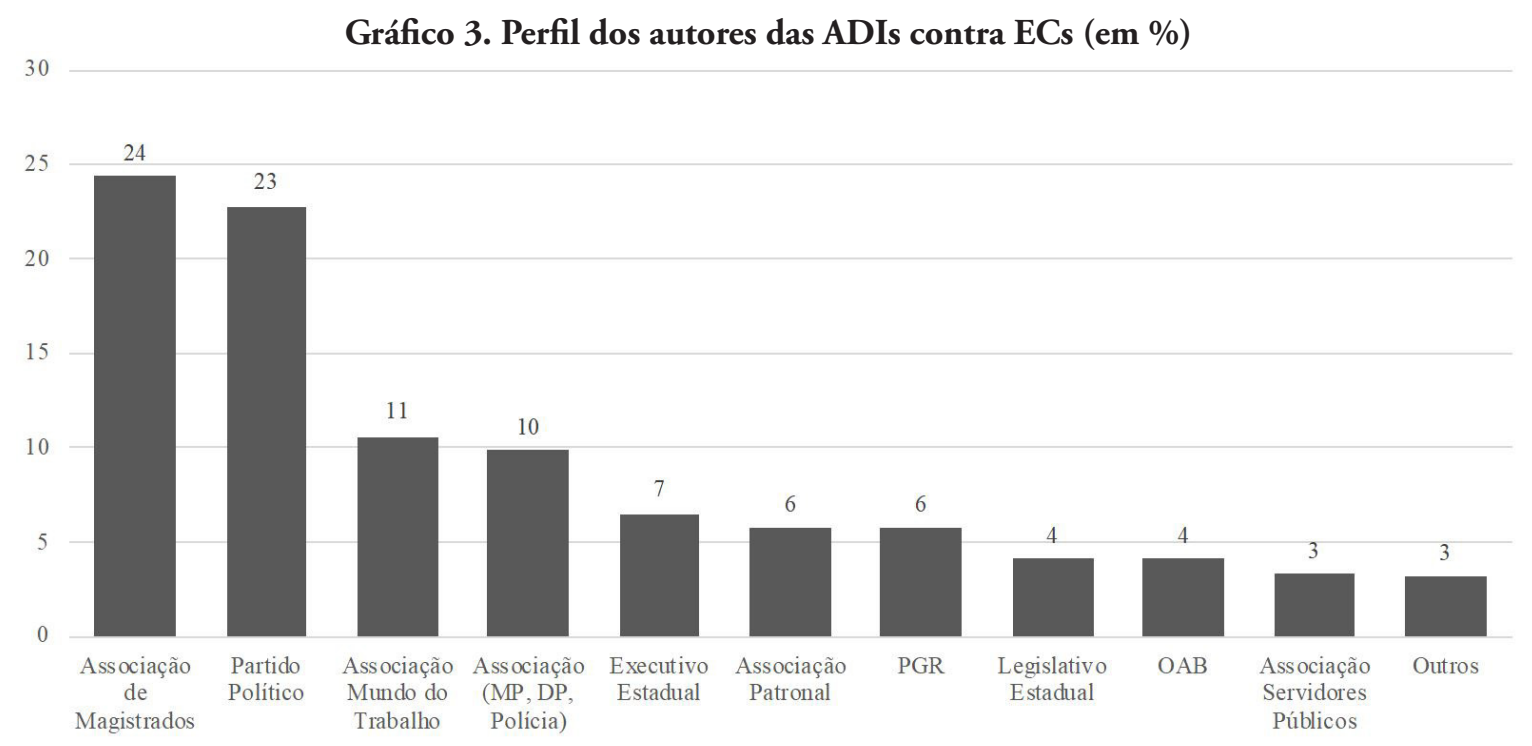

Base: 123 pedidos; Fonte: Pesquisa Fapesp

Tabela 4.

Os dez maiores litigantes contra ECs em ADIs

\begin{tabular}{lcc}
\hline \multicolumn{1}{c}{ Ator (litigante) } & $\begin{array}{c}\text { Número de ADIs } \\
\text { propostas }\end{array}$ & $\begin{array}{c}\text { \% sobre o total } \\
\text { de ADIs contra } \\
\text { ECs }\end{array}$ \\
\hline Associação dos Magistrados Brasileiros (AMB) & 14 & $12 \%$ \\
\hline Associação Nacional dos Magistrados da Justiça do Trabalho (ANAMATRA) & 13 & $11 \%$ \\
\hline PDT & 8 & $7 \%$ \\
\hline Procuradoria-Geral da República & 7 & $6 \%$ \\
\hline PT & 6 & $5 \%$ \\
\hline PC do B & 6 & $5 \%$ \\
\hline Associação Nacional dos Magistrados Estaduais (ANAMAGES) & 5 & $4 \%$ \\
\hline Associaçáo Nacional dos Membros do Ministério Público (CONAMP) & 5 & $4 \%$ \\
\hline Conselho Federal da Ordem dos Advogados do Brasil (OAB) & 5 & $4 \%$ \\
\hline PSB & 5 & $4 \%$ \\
\hline Base: 115 ADIs & & \\
\hline Fonte: Pesto
\end{tabular}

Fonte: Pesquisa Fapesp 
Os partidos políticos derrotados no processo de criaçáo de emendas vêm em segundo lugar, com $23 \%$ das açóes. Esse dado precisa ser interpretado considerando uma especificidade desse ator diante dos demais legitimados para propor ADI. Como já observamos, pela jurisprudência consolidada do STF parlamentares têm legitimidade para propor mandados de segurança individuais junto ao STF, durante a tramitaçáo legislativa de uma proposta de emenda à Constituição. Esses MS são utilizados, com frequência crescente, para alegar que a tramitação da PEC violou regras procedimentais; mas também podem ser empregados para antecipar uma discussão sobre a compatibilidade da PEC com as "cláusulas pétreas" da Constituição. ${ }^{10}$ Assim, o comportamento que observamos dos partidos políticos quanto à judicialização de emendas à constituição pode ser resultado, também, de aprendizado ou comportamento estratégico informado por tentativas anteriores de barrar a PEC correspondente no STF, por meio de MS de parlamentares individuais. ${ }^{11} \mathrm{Ou}$ seja, é possível que a decisão de (não) ajuizar uma ADI contra uma EC seja moldada pelo resultado de rodadas anteriores de interação entre parlamentares e o STF, durante o processo legislativo, em mandados de segurança contra PECs ligadas ao tema.
As associaçóes do mundo do trabalho e os governadores aparecem na sequência, com $11 \%$ dos pedidos cada. As entidades patronais e a PGR têm cada uma 6\% dos pedidos. As associaçôes de servidores públicos que não das carreiras da Justiça representam 3\% dos pedidos. Na categoria "Outros" foram classificados pedidos de organizaçóes náo-governamentais (ONGs) e do Executivo Federal.

Entre os dez maiores litigantes pela inconstitucionalidade de ECs (Tabela 4) há três associaçóes de magistrados, uma associaçáo de membros do Ministério Público, a OAB e a Procuradoria-Geral da República. Outros quatro são partidos políticos: PDT, PC do B, PT e PSB. As associaçóes de magistrados, de outras carreiras públicas do direito e de servidores públicos atuaram sobretudo na temática que afeta suas carreiras. O Legislativo estadual também litigou majoritariamente nessa temática (Tabela 5).

Já as associaçóes do mundo do trabalho concentram sua litigância em $\mathrm{ADIs}$ contra emendas constitucionais envolvendo política fiscal, que afetam diretamente a alocação de recursos nas políticas de saúde e educação. Os dados indicam que a OAB e a PGR têm duas áreas prioritárias de contestação de emendas: política fiscal e sistema político eleitoral. Os partidos políticos, por sua vez, questionaram primariamente reformas constitucionais que afetam as carreiras públicas, depois

Tabela 5.

Perfil temático das ADIs, de acordo com requerente

\begin{tabular}{lcccccc}
\hline \multicolumn{1}{c}{ Requerente/ Tema } & $\begin{array}{c}\text { Servidor } \\
\text { e agente } \\
\text { público }\end{array}$ & $\begin{array}{c}\text { Política } \\
\text { fiscal e } \\
\text { tributária }\end{array}$ & $\begin{array}{c}\text { Administraçáo } \\
\text { da Justiça }\end{array}$ & $\begin{array}{c}\text { Sistema } \\
\text { Político- } \\
\text { eleitoral }\end{array}$ & $\begin{array}{c}\text { Direitos e } \\
\text { sociedade } \\
\text { civil }\end{array}$ & $\begin{array}{c}\text { Administraçáo } \\
\text { pública }\end{array}$ \\
\hline Associação de magistrados & $70 \%$ & $10 \%$ & $20 \%$ & - & - & - \\
\hline Associação (MP, DP, Polícia) & $58 \%$ & $8 \%$ & $25 \%$ & $8 \%$ & - & - \\
\hline Associação servidores públicos & $75 \%$ & $25 \%$ & - & - & - & - \\
\hline PGR & $14 \%$ & $29 \%$ & $14 \%$ & $29 \%$ & $14 \%$ & - \\
\hline OAB & - & $60 \%$ & - & $40 \%$ & - & - \\
\hline Executivo Estadual & $38 \%$ & $50 \%$ & - & $13 \%$ & - & - \\
\hline Legislativo Estadual & $60 \%$ & - & - & - & - & $40 \%$ \\
\hline Associação mundo do trabalho & - & $62 \%$ & $31 \%$ & - & $8 \%$ & - \\
\hline Partido Político & $43 \%$ & $32 \%$ & - & $18 \%$ & $7 \%$ & - \\
\hline Associação Patronal & - & $86 \%$ & $14 \%$ & - & - & - \\
\hline Outros & $25 \%$ & $25 \%$ & $25 \%$ & - & $25 \%$ & - \\
\hline Total & $42 \%$ & $31 \%$ & $13 \%$ & $9 \%$ & $4 \%$ & $2 \%$ \\
\hline Base: & & & & & \\
\hline
\end{tabular}

Base: 123 pedidos; Fonte: Pesquisa Fapesp 
a política fiscal e tributária, e apenas residualmente temas da sociedade civil.

A predominância que observamos de entidades ligadas ao sistema de Justiça, configurando o controle abstrato de emendas como um "diálogo restrito", é um resultado esperado em certas áreas temáticas do controle abstrato de constitucionalidade, considerando estudos anteriores. Nesse sentido, por exemplo, Ribeiro e Arguelhes (2015, pp. 484-486) observam que, no período de 2005 a 2013, associaçóes de magistrados foram responsáveis por $63 \%$ de todas as ADIs ajuizadas contra atos normativos do Conselho Nacional de Justiça; e duas associações específicas, a ANAMAGES e a AMB, responderam por vinte de um total de 27 ações.

Quais os principais fundamentos das açöes contra ECs?

No que se refere à fundamentação das petições, a principal justificativa para impugnar as ECs foi a vedação a emendas que tendiam a abolir direitos e garantias individuais, que fundamenta $58 \%$ dos pedidos (Tabela 6). Os principais direitos e garantias individuais invocados nessas açốes são: a proteção ao direito adquirido (13\%); a igualdade ou isonomia (10\%); o acesso à jurisdição e à Justiça (7\%); e o direito à seguridade social, saúde ou educação $(6 \%)$. Citados em menor proporçáo estáo o direito à vida (2\%) e o direito fundamental ao meio ambiente ecologicamente equilibrado (1\%).

$\mathrm{O}$ desrespeito aos limites formais no processo legislativo de emenda à constituição apareceu como justificativa em $20 \%$ do total de pedidos, com maior destaque nos temas de administração da Justiça. A violação ao princípio da separação de poderes fundamentou $11 \%$ dos pedidos, com destaque para os temas relativos à competição político-eleitoral. A alegação de violação ao princípio federativo fundamentou $9 \%$ dos pedidos.

O destaque da categoria "Direitos e Garantias Individuais" precisa ser interpretado no contexto da predominância, dentro desse tema, de questóes ligadas às reformas constitucionais do judiciário, da administração e do serviço público. Mais especificamente, é preciso ler esse resultado no contexto da atuação organizada dos interesses afetados por reformas que impactam a administração da Justiça e servidores e agentes públicos de forma geral, que correspondem a $30 \%$ de todas as $\mathrm{ADI}$ s, e que aparecem com destaque em outras dimensóes dos resultados discutidos nesta seção. Considere, nesse sentido, a preponderância relativa de argumentos de proteção a "direitos adquiridos" e "igualdade e isonomia" nessas ADIs. Esse dado pode apontar para uma relativa "captura" da pauta da judicialização de emendas por interesses corporativos, também já documentada em estudos anteriores sobre quem aciona a jurisdição do STF no controle abstrato de constitucionalidade (Oliveira, 2016; Costa e Benvindo, 2014). Mais ainda, como veremos na próxima seção, ela se reflete também nas reaçôes do STF à judicialização de emendas constitucionais.

Tabela 6.

Fundamentaçáo dos pedidos, de acordo com o tema da EC

\begin{tabular}{lccccccc}
\hline \multicolumn{1}{c}{ Fundamentaçáo } & $\begin{array}{c}\text { Servidor } \\
\text { público }\end{array}$ & $\begin{array}{c}\text { Política } \\
\text { fiscal e } \\
\text { tributária }\end{array}$ & $\begin{array}{c}\text { Adm. } \\
\text { Justiça }\end{array}$ & $\begin{array}{c}\text { Político- } \\
\text { eleitoral }\end{array}$ & $\begin{array}{c}\text { Direitos e } \\
\text { sociedade } \\
\text { civil }\end{array}$ & $\begin{array}{c}\text { Adm. } \\
\text { pública }\end{array}$ & Total \\
\hline Direitos e garantias individuais & $55 \%$ & $66 \%$ & $44 \%$ & $55 \%$ & $100 \%$ & - & $58 \%$ \\
\hline Limites formais & $20 \%$ & $21 \%$ & $31 \%$ & $9 \%$ & - & - & $20 \%$ \\
\hline Separaçáo de poderes & $14 \%$ & $3 \%$ & $19 \%$ & $27 \%$ & - & - & $11 \%$ \\
\hline Federação & $8 \%$ & $11 \%$ & $6 \%$ & $9 \%$ & - & $50 \%$ & $9 \%$ \\
\hline Omissão & $4 \%$ & - & - & - & - & $50 \%$ & $2 \%$ \\
\hline $\mathbf{N}$ & $\mathbf{5 1}$ & $\mathbf{3 8}$ & $\mathbf{1 6}$ & $\mathbf{1 1}$ & $\mathbf{5}$ & $\mathbf{2}$ & $\mathbf{1 2 3}$ \\
\hline
\end{tabular}

Fonte: Pesquisa Fapesp 


\section{Como o Supremo Tribunal Federal respondeu a essas açóes?}

\section{Quantos pedidos foram bem-sucedidos?}

Até agosto de 2018, o STF havia proferido decisão final para praticamente metade dos pedidos de inconstitucionalidade de ECs (Gráfico 4). Outros $13 \%$ dessas açôes, embora não tivessem decisão final, já haviam passado por julgamento de liminar, restando assim 38\% dos pedidos em ADI sem nenhuma resposta. Considerando os generosos e variados mecanismos (formais e informais) de que o tribunal dispóe para montar sua agenda e decidir o que e quando decidir (Arguelhes e Hartmann, 2017; Dimoulis e Lunardi, 2008), não é surpreendente que, mesmo em um universo pequeno de ADIs, uma parcela grande de açóes ainda náo tenha sido objeto de decisão. Esse fenômeno já foi observado em diversos outros estudos, a partir de diferentes ângulos, sobre as práticas decisórias do tribunal (Oliveira, 2017; Ribeiro e Arguelhes, 2015; Oliveira, 2005).

O STF não conheceu ou julgou prejudicados $30 \%$ dos pedidos, e indeferiu, no mérito, outros $11 \%$. $\mathrm{O}$ tribunal julgou procedente, no todo ou em parte, $9 \%$ dos pedidos, e concedeu liminar a outros $11 \%$. Assim, em um quinto das vezes o Supremo respondeu favoravelmente, in totum ou em parte, a atores que o provocaram, em ADI, para limitar a mudança da Constituição. Essas decisões de procedência total ou parcial afetaram, em graus variados, o conteúdo de

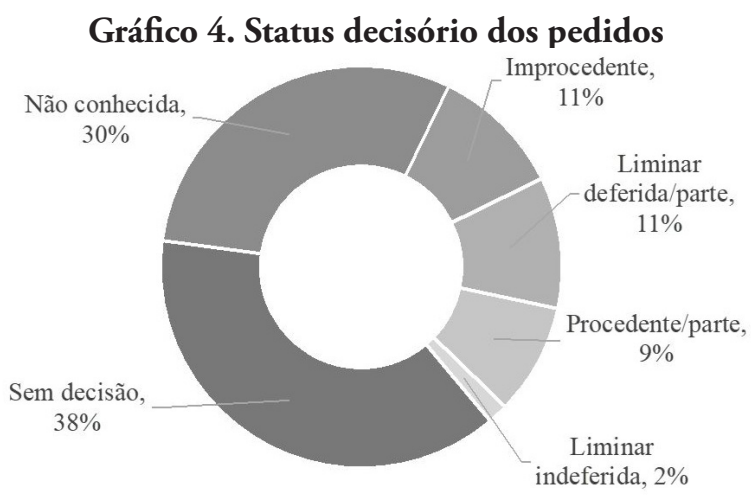

Base: 123 pedidos; Fonte: Pesquisa Fapesp quinze das 35 emendas constitucionais contestadas junto ao STF. Assim, o tribunal interferiu no conteúdo de $42,8 \%$ do total de emendas que foram objeto de contestação judicial por ADIs. Esse percentual pode ser considerado alto quando observamos outros dados disponíveis sobre o STF-como, por exemplo, que o tribunal considerou total ou parcialmente procedentes $33 \%$ de um total de 2.712 ADIs que julgou até 2014 (Oliveira, 2016).

Embora este trabalho não tenha uma finalidade comparativa, é útil ler esses dados a partir de alguns parâmetros iniciais, ainda que imperfeitos, criados com dados disponíveis de outros países. Num intervalo de tempo mais próximo ao analisado para o STF, de 1988 a 2017, a Suprema Corte dos EUA decidiu pela inconstitucionalidade de leis questionadas em 6,1\% de um total de 2.753 casos apreciados. ${ }^{12}$ De 1990 a 2010, o Tribunal Constitucional do Chile declarou leis inconstitucionais em 19,7\% dos 933 casos que julgou (Tiede, 2015). Na Suprema Corte do Uruguai, de 1990 a 2018, de 3.044 decisões definitivas em controle de constitucionalidade, 867 resultaram na declaração de inconstitucionalidade (ao menos parcial) de um ou mais dispositivos legislativos de 46 leis (Antía e Vairo, 2019), isto é, o tribunal reconheceu inconstitucionalidade em cerca de $28,5 \%$ das decisões.

Esses percentuais se referem a declarações de inconstitucionalidade em geral, e não especificamente ao controle judicial de emendas. Eles são preliminarmente úteis, porém, se assumirmos a posição corrente na teoria constitucional de que o poder de controle judicial de emendas à Constituição é excepcional (e.g., Roznai, 2013), em dois sentidos. Primeiro, do ponto de vista descritivo, a maioria das constituiçóes em vigor hoje no mundo não preveem limites materiais a emendas constitucionais, e um número ainda menor de textos constitucionais confere expressamente a tribunais o poder de fazer esse controle. Segundo, mesmo quando previsto no texto constitucional ou reconhecido pela prática dos tribunais, juristas tendem a considerar que esse poder "extremo" deve ser utilizado apenas em "casos graves e circunstâncias excepcionais" (Roznai, 2017, pp.195-196), como uma "arma do juízo final" (Roznai, 2017, p. 235) contra violaçôes ao núcleo essencial da Constituiçăo. ${ }^{13}$ 
Essa visão normativa da intervenção judicial quanto ao conteúdo de emendas constitucionais como algo excepcional, ainda que admitido, parece encontrar algum eco no comportamento de diversos tribunais. Apenas a título exemplificativo, considere que a Suprema Corte da Índia declarou inconstitucionalidade em apenas sete emendas à constituição do país, de 1967 (quando reconheceu para si esse poder, no caso GolakNath) a 2019. Trata-se de uma corte suprema considerada particularmente agressiva no uso desse poder, e de uma constituição emendada com relativa frequência. ${ }^{14}$ A Suprema Corte da Argentina reconheceu este poder no caso Fayt, decidido em 1999 (Sabsay, 1999) e o único, até hoje, em que a corte declarou uma emenda constitucional inconstitucional.

É certo que os contextos políticos e institucionais, inclusive as características dos próprios textos constitucionais, são bastante diferentes em todos esses países. Considerando variaçooes na configuração do processo decisório e do direito processual entre esses países, é preciso cautela ao fazer comparaçóes sem utilizar uma metodologia uniforme. Como pontuamos, nosso objetivo não é comparativo. A observação desses percentuais e números absolutos, mesmo com todas essas cautelas, contudo, torna em princípio difícil sustentar que a frequência de intervenção do STF nas emendas contestadas em ADIs seria baixa ou pouco significativa.

Mais uma vez, mesmo entre os países que conferem esse tipo de poder aos seus tribunais, o fato de o Supremo Tribunal Federal ter reconhecido alguma inconstitucionalidade em quinze emendas, ao longo de trinta anos - e, em alguns casos, por meio de liminares individuais, como veremos - sugere que o tribunal não deve ser considerado "contido" no uso deste poder. A "arma do juízo final” parece integrar o repertório normal de poderes na zona de conforto institucional do tribunal. ${ }^{15}$

\section{Quais atores e interesses processuais prevaleceram} nessas decisóes?

Nas ADIs em que atuou sobre o conteúdo de mudanças constitucionais, o STF interveio sobretudo para vetar alteraçóes nas carreiras públicas da Justiça, em tributos e precatórios, e nos temas afeitos aos direitos sociais. Contudo, atuou pouco em casos envolvendo mudanças na política fiscal, e não fez intervençóes (ou ainda não fez) em casos como a instituição do Fundo Social de Emergência, no FUNDEF, na DRU e no teto dos gastos. Neste último caso, porém, pode ter aberto um precedente ao conceder monocraticamente uma liminar na $\mathrm{ADI}$ 5595 que questionou a EC 86/2015, referente ao custeio da saúde, decidindo que a participaçáo no resultado ou compensação financeira pela exploração de petróleo e gás natural não podem ser computadas para fins de cumprimento do disposto no inciso I do $\$ 2^{\circ}$ do art. 198 da Constituição Federal.

O STF atendeu a seis pedidos de impugnação da EC 41 (Gráfico 5). Desses pedidos, cinco eram de autoria de associaçóes de carreiras da Justiça (Associação Nacional dos Membros do Ministério Público; Associação Nacional dos Procuradores da República; Associação dos Delegados de Polícia do Brasil; Associação dos Magistrados Brasileiros; e Associação Nacional dos Magistrados Estaduais) e um do PTB. O Tribunal considerou inconstitucional haver bases de cálculos diferenciadas para tributação, dado o princípio de isonomia tributária, e também a existência de dois tetos diferentes para a magistratura, federal e estadual. ${ }^{16}$

No caso da EC 30/2000, o STF decidiu que o parcelamento no pagamento de precatórios violou o direito adquirido do beneficiário. ${ }^{17} \mathrm{E}$, quanto à EC 62/2009, considerou inválida a limitação da preferência a idosos que completem 60 anos até a expedição do Precatório, por discriminação arbitrária e violação à isonomia. ${ }^{18}$ Ainda no tema dos precatórios, o ministro Barroso deferiu parcialmente cautelar para conferir interpretação conforme à EC 94/2016, especificando que a utilizaçáo dos recursos de depósitos judiciais pelos Estados para pagamento de precatórios deve observar condições específicas. ${ }^{19}$

As duas decisões favoráveis à impugnação de dispositivos da EC 45/2004 são liminares: uma para excluir da competência da Justiça do Trabalho as causas entre o Poder Público e seus servidores estatutários, por não se reputarem oriundas de relação de trabalho; outra, para afastar da Justiça do Trabalho competência para julgamento de matéria criminal. ${ }^{20}$ Outra decisão liminar que interferiu em emenda 


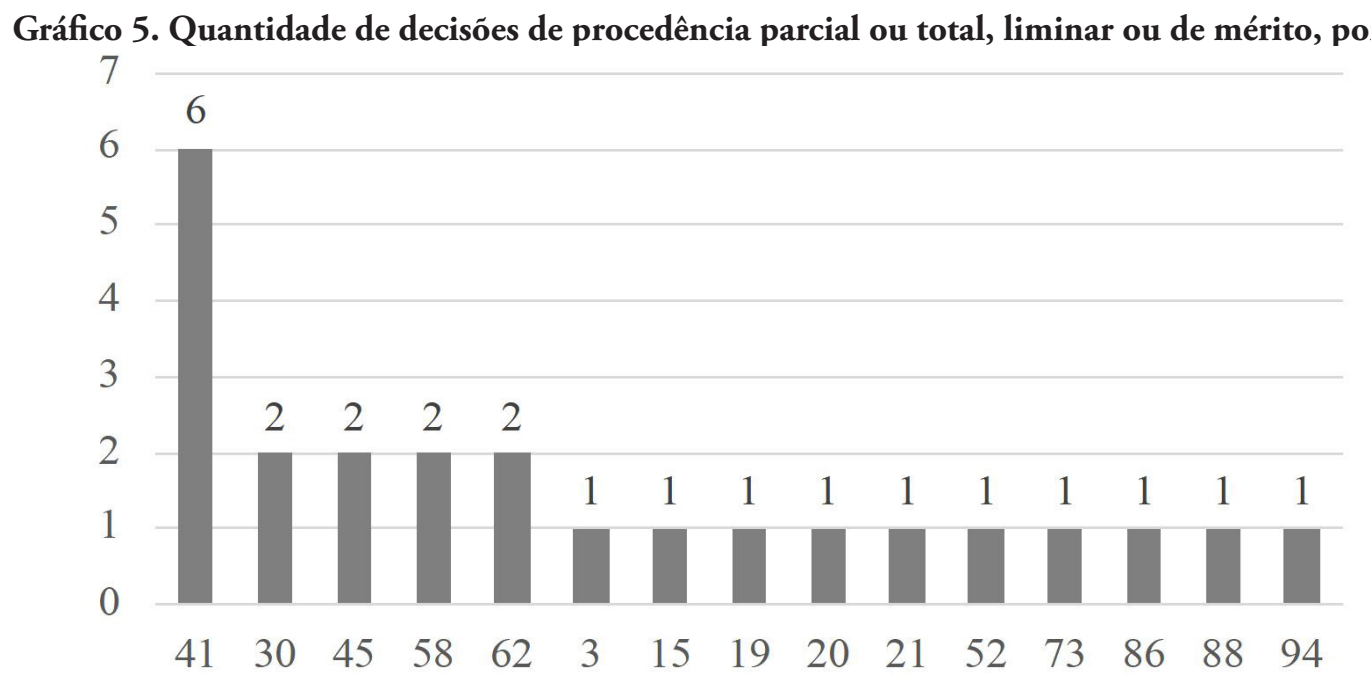

Base: 24 pedidos com liminar deferida ou mérito procedente (total ou em parte); Fonte: Pesquisa Fapesp

sobre regulação da Justiça ocorreu na ADI 5017, que suspendeu a criação dos Tribunais Regionais Federais das $6^{\mathrm{a}}, 7^{\mathrm{a}}, 8^{\mathrm{a}}$ e $9^{\mathrm{a}}$ regióes.

O Supremo interveio em emendas relativas a questóes político-eleitorais, como a EC 58/2009, que trata da recomposição das Câmaras Municipais, ${ }^{21}$ considerando que a retroatividade dos efeitos das regras constitucionais de composição das Câmaras Municipais em pleito ocorrido e encerrado constitui ofensa ao pleno exercício da cidadania popular e à segurança jurídica. Na ementa da ADI 4307 lê-se que

$\mathrm{Na}$ Constituição da República não há referência a suplente de vereador. Suplente de Deputado ou de Senador: convocaçáo apenas para substituição definitiva; inviável criaçáo de mandato por aumento da representação.

Nessa mesma temática, a EC 52/2006, que disciplinou as coligaçôes eleitorais, também teve ingerência do STF. No julgamento da ADI 3685 o Tribunal determinou que a verticalização das coligaçōes partidárias permaneceria válida nas eleiçóes de 2006, sendo a não obrigatoriedade de vinculação entre as candidaturas - em âmbito nacional, estadual, distrital ou municipal - aplicável apenas depois de decorrido um ano da vigência da emenda.
O Supremo interferiu em questóes tributárias, tanto no IPMF (EC 3/1993) quanto na CPMF (EC 21/1999), nas ADIs 939 e 2031. Declarou estado de mora do Congresso frente à EC 15/ 1996, na ADI 3682. E decidiu que a aposentadoria aos 75 anos de idade não pode ser estendida a outros agentes públicos até que seja editada a lei complementar, na ADI 5316 que contestou a EC 88/2015.

$\mathrm{Na}$ temática de direitos, o STF excluiu a aplicação do limite máximo para o valor dos benefícios do regime geral de previdência social ao salário da licença-maternidade, na ADI 2946 que arguia a inconstitucionalidade da EC 20/1998. Finalmente, no julgamento da ADI 2135, o Supremo reconheceu a inconstitucionalidade por vício formal do caput do art. 39 da EC 19/1998, que criava o contrato de emprego público.

\section{Dinâmica interna do tribunal}

Com relaçáo ao processo decisório interno do tribunal, um aspecto que merece atenção é a permanência das liminares deferidas. Em média, elas têm 7,5 anos, sendo que a liminar mais antiga vigente em agosto de 2018 tinha sido concedida 11,7 anos antes (Tabela 7). Trata-se da ADI 3395, proposta pela AJUFE contra aspectos da EC 45/2004 
Tabela 7.

Tempos de tramitaçáo (em anos)

\begin{tabular}{lccc}
\hline & ADI tramitando & Até decisão liminar & Até decisáo final \\
\hline Média & 8,8 & 2,5 & 2,8 \\
\hline Mediana & 10,5 & 0,4 & 1,5 \\
\hline Desvio Padrão & 5,8 & 3,6 & 3,5 \\
\hline Mínimo & 0,3 & 0 & 0 \\
\hline Máximo & 20,4 & 9,9 & 13 \\
\hline $25 \%$ & 3,2 & 0,1 & 0 \\
\hline $75 \%$ & 13,5 & 3,1 & 4 \\
\hline
\end{tabular}

Base: 123 pedidos; Fonte: Pesquisa Fapesp

(Reforma do Judiciário). Em média, as ações que tiveram julgamento cautelar tramitaram por 2,5 anos até obter a decisão final. A vigência de liminares por longos períodos na prática decisória do STF, inclusive no controle de constitucionalidade em ADIs, já havia sido apontada em outros trabalhos empíricos (Falcão, Hartmann e Chaves, 2014).

Contudo, os dados que encontramos no caso das emendas são particularmente surpreendentes, se considerarmos, novamente, a tese da excepcionalidade do controle judicial sobre seu conteúdo. Manter uma emenda constitucional suspensa por anos com uma liminar deveria ser, em tese, ainda mais excepcional do que fazer o mesmo com uma lei ordinária ou outro ato normativo infraconstitucional. Mas, no período de 1988 a 2013, as liminares concedidas em ADIs no STF permaneceram vigentes na média por 6,1 anos até serem apreciadas pelo plenário (Falcão, Hartmann e Chaves, 2014, p. 41). Embora o período analisado não seja idêntico, trata-se de um indício de que é possível que as liminares envolvendo emendas à Constituição tendam a permanecer vigentes por mais tempo do que das ADIs contra outros atos normativos. Mais ainda, encontramos nessa situação três liminares concedidas monocraticamente - nas ADIs 5017, 5595 e 5679. São casos problemáticos de intervenção judicial contra mudanças constitucionais que, além de precária, é também individual, aparentemente sem controle efetivo pelo plenário do tribunal ao longo do tempo. ${ }^{22}$
A ação que levou mais tempo até o julgamento cautelar foi a ADI 2356, na qual a Confederação Nacional da Indústria questionou aspectos da EC 30/2000, referentes ao pagamento de precatórios. O STF recebeu a ação em 28 de novembro de 2000 e concedeu liminar apenas em 25 de novembro de 2010.

Das açôes com decisão final, metade foi decidida em até um ano e meio. As que tramitaram mais rápido tiveram decisão final em menos de um mês (como, por exemplo, a ADI 926). A mais lenta demorou treze anos até a decisão final (ADI 2732). Entre as açôes sem decisão final, metade está em tramitação há mais de uma década. A ADI 1805, que questiona a EC 16/1997 no aspecto que trata da reeleição, tramita há duas décadas. A ação foi proposta pelos partidos políticos PDT, PT, PC do B e PL, arguindo a necessidade de desincompatibilização dos titulares do Poder Executivo para concorrer à reeleição até seis meses antes do pleito. Teve a cautelar indeferida em 26 de março de 1998, ficando vencido o ministro Marco Aurélio, que deferia a liminar nos termos pretendidos pelos autores.

Por fim, no que se refere ao processo decisório em si, das ações com decisão final, 39\% foram decididas por maioria, isto é, incluíram ao menos um voto vencido; $36 \%$ foram monocráticas e $25 \%$, unânimes. Essa configuração destoa do padrão geral para ADIs, que tende a ser mais unânime (Oliveira, 2017). Observou-se que os ministros que se posicionaram na minoria com maior frequência foram Marco Aurélio (79\%), Pertence (42\%), Britto $(32 \%)$ e Velloso (26\%). 


\section{Conclusão}

Os dados descritivos aqui apresentados mostram que, no Brasil, a contestação a emendas constitucionais pela via judicial é um fenômeno frequente, que faz parte do processo político nacional - tanto quanto a própria adoção de emendas à Constituição. Uma vez que a mudança constitucional seja discutida na arena judicial, porém, ao menos no caso das ADIs, os temas, participantes e beneficiários desse processo de judicializaçấo estấo distribuídos de maneira bastante assimétrica, com grande peso de interesses corporativos em todas essas dimensôes. Quem mais tem buscado limitar a mudança constitucional por meio de ADIs são as associações de carreiras públicas da Justiça. Em particular, as associaçóes de magistrados se constituíram como os principais "clientes" da jurisdiçẫo em controle abstrato do STF no questionamento de ECs, buscando sistematicamente defender seus interesses corporativos.

O Supremo náo tem permanecido inerte ou contido em sua resposta a essas provocaçóes. Pelo contrário, o tribunal utilizou seu poder de controle para interferir, em decisōes de mérito ou liminares, em $42,8 \%$ das emendas constitucionais submetidas à sua jurisdição em controle abstrato de constitucionalidade. De fato, em quinze das 35 emendas contestadas em ADIs de 1998 a 2018, como vimos, o Tribunal (ou um de seus ministros) suspendeu, limitou ou modulou as mudanças constitucionais aprovadas pelo Congresso. Estudos comparativos sistemáticos são necessários para contextualizar e interpretar esse dado. Indicando apenas direções preliminares de leitura comparativa, observamos que o percentual de $42,8 \%$ parece suficientemente alto, em comparação com dados pontuais disponíveis sobre alguns outros países, para por em dúvida a ideia de que o STF utilizaria esse poder de forma parcimoniosa, tímida ou contida.

Quando analisada "no atacado", a agenda decisória do Supremo permite pensar em outro papel que desempenha, para além das funçóes clássicas de defesa e incorporaçáo de minorias ao processo político decisório ("contra-majoritárias"), ou de mediação de conflitos entre os poderes Executivo e Legislativo. Os dados deste trabalho se somam aos de outros estudos para sugerir que o STF tem também desempenhado o papel de eficaz órgáo de deliberação corporativa, atuando quase como um setor de "recursos humanos" da administração pública (Oliveira, 2016, pp. 116-117). Esse acentuado sucesso, na pauta judicial sobre mudança constitucional, de interesses corporativos ligados à administraçấo pública tem implicaçóes relevantes para análises do papel das emendas constitucionais no processo político nacional.

Ao discutirem a alta taxa de reforma da Constituiçáo de 1988, Arantes e Couto observam que quase 55\% dos dispositivos de emendas aprovadas se destinavam a adicionar novos aspectos ao texto, que seria hoje 44\% maior do que sua versão original de 1988. Esse resultado desafia a ideia de que o detalhamento e extensão do texto original tornariam inevitável governar por meio de emendas, já que boa parte das mudanças funcionaram para ampliar o texto, náo para reduzi-lo ou alterá-lo. Para explicar esse achado, os autores argumentam que a produção normativa do processo político está sujeita a vetos judiciais, em especial do STF, acessível a um grande número de atores (Arantes e Couto, 2019, p. 37). Nesse cenário, a alta taxa de emendas (inclusive aditivas) ao texto constitucional refletiria uma estratégia voluntária de prevenção, por parte dos atores políticos, contra dois pontos de veto na produção e implementaçấo legislativa: "o federalismo e o controle constitucional pelo judiciário" (Arantes e Couto, 2019, p. 38).

Assim, utilizando emendas inclusive quando elas não seriam estritamente necessárias, maiorias governantes tornariam menos provável que minorias federativas e outros interesses derrotados no processo legislativo tenham sucesso, no Supremo ou perante qualquer juiz ou tribunal, ao alegar que uma dada política pública viola a Constituiçấo ou seu sistema de competências (Arantes e Couto, 2019, p. 45). Contudo, como observam os autores, as "cláusulas pétreas" apareceriam aqui como um super veto point (2019, p. 38), capaz de ainda assim fornecer muniçấo jurídica para uma eventual contestação judicial da mudança constitucional. Os dados apresentados neste artigo indicam que o veto judicial alimentado pelas "cláusulas pétreas" não é necessariamente especulativo, nem excepcional. A ameaça de intervenção judicial na produçáo de emendas tem se concretizado com 
frequência suficiente para ser considerada parte da política constitucional brasileira. Mais ainda, o gatilho de acionamento do super veto point parece ser particularmente responsivo a emendas que conflitem com os interesses de magistrados e outras carreiras públicas da Justiça.

Essas análises, consideradas em conjunto com os dados aqui apresentados, permitem levantar a hipótese (bastante plausível) de que o Supremo compartilha os valores da coalizão política majoritária, desde que tais preferências não contrariem um conjunto específico de interesses corporativos. A mudança constitucional é frequente no Brasil, em termos comparativos. Mas também são frequentes sua contestação e seu veto pelo Supremo Tribunal Federal. Entre a mudança efetiva e o veto, as associaçóes das carreiras públicas da Justiça construíram um espaço fértil para a defesa de seus interesses, encontrando nas ADIs um eficaz instrumento de manutenção do status quo até mesmo no controle de emendas constitucionais - um poder judicial que, em tese, deveria ser de uso excepcional, ainda quando expressamente previsto na Constituição.

\section{AGRADECIMENTOS}

A base de dados utilizada neste trabalho foi construída com suporte financeiro da FAPESP (18/00395-9 e 13/08188-9). Os autores agradecem a Natalia Pires de Vasconcelos e aos pareceristas anônimos da RBCS pelos comentários; a Evandro Süssekind pelo auxílio na pesquisa; e a Mariana Muniz pelo auxílio na revisão do texto.

\section{Notas}

1 Parte-se aqui da premissa de que a previsão de limites ao poder de emendar a Constituição não implica automaticamente a previsão do controle judicial desses limites, que poderia estar (e está, em alguns países) expressamente previsto. Essa premissa é aceita em trabalhos comparativos sobre o tema. Em obra recente e abrangente sobre "cláusulas pétreas" em sistemas jurídicos ao redor do mundo, Yaniv Roznai registra o Brasil como um caso em que mesmo sem "autoridade expressa", no texto, para realizar controle de emendas, essa atuação judicial teria se tornado uma "prática estabelecida"
(Roznai, 2017, p. 204). O autor observa que a maioria das constituiçóes contemporâneas é silente quanto a essa questão, e, na ausência de regulação constitucional expressa, a legalidade do controle judicial de emendas é questionável (2017, pp. 202-203).

2 O entendimento de que parlamentares teriam um direito individual à aplicaçáo das regras constitucionais de processo legislativo permitiu inclusive que a PEC das "Diretas Já" fosse contestada no STF. Ver Arguelhes e Süssekind, 2018 e Oliveira, 2004.

3 Nosso foco neste artigo são as ADIs. No direito brasileiro, porém, como já observamos, emendas à constituição podem ser contestadas também no âmbito de quaisquer processos, em controle incidental de constitucionalidade, realizado por qualquer juiz ou tribunal. Existem ainda alguns casos importantes de contestação da constitucionalidade de propostas de emenda à constituição (PECs), por meio de Mandados de Segurança impetrados já no processo legislativo por parlamentares individuais, tanto por vícios procedimentais quanto por violação de cláusulas pétreas (ver Süssekind, 2017).

4 Em 2019 foram promulgadas seis ECs (n. 100 a n.105), que não analisamos aqui, por estarem fora do período coberto pelo trabalho.

5 No mérito, por decisão majoritária, as ações foram consideradas improcedentes, ficando vencidos os ministros Marco Aurélio e Carlos Velloso, que as julgavam procedentes, e parcialmente vencido o ministro Sepúlveda Pertence, que as julgava parcialmente procedentes.

6 Posteriormente, em 2 de março de 1994, o Tribunal, resolvendo questão de ordem, julgou prejudicada a ADI 926, por perda de objeto, uma vez que os dispositivos questionados nessa ação já haviam sido declarados inconstitucionais no julgamento do mérito da ADI 939.

7 A decisão declarou a inconstitucionalidade da expressão “o art. 150 , III, b e VI, contida no $\$ 2^{\circ}$ do art. $2^{\circ}$ da EC n. 3/1993, por violação aos princípios da anterioridade e da imunidade tributária recíproca, além da imunidade de templos de qualquer culto; patrimônio, renda ou serviços dos partidos políticos, entidades sindicais dos trabalhadores e instituiçóes de educação e de assistência social, sem fins lucrativos; e sobre livros, jornais, periódicos e o papel destinado à sua impressão.

8 A classificação do objeto de questionamento na ADI foi desenvolvida a partir da leitura da petição inicial, considerando, ainda, o sentido do pedido apresentado no relatório da ADI. Ou seja, foram considerados os argumentos apresentados pelo autor da ação no questionamento da EC, levando em conta o objeto principal do pedido. Essa metodologia de classificação segue procedimento proposto por Oliveira (2016). 
9 É curioso notar que a ADI 3.367, na qual a AMB arguiu de inconstitucionalidade a EC 45/2004, deu entrada no STF em 16 dez. 2014, 21 dias antes de sua promulgação. O ministro Cezar Peluso, relator da ação, proferiu um despacho solicitando aguardar a publicaçáo da emenda, para que os autos voltassem conclusos ao relator. Uma análise completa desse resultado envolveria incorporar os questionamentos apresentados ainda no processo legislativo, antes mesmo da aprovaçáo formal das emendas, por meio de mandados de segurança. É possível que os padrốes de judicializaçáo (e de resposta do STF) na fase legislativa ajudem a explicar padrôes de contestação a emendas já aprovadas.

10 Ver Süssekind (2017).

11 Para uma tentativa de integrar a literatura sobre "judicialização da política" com esse poder individual dos parlamentares, ver Ribeiro e Arguelhes (2019).

12 Por meio de pesquisa livre na ferramenta disponibilizada pela Washington University, de 1988 a 2017, observamos que a Suprema Corte Americana julgou 2.753 casos, incluindo atos do Congresso, Estaduais e de ordem municipal, tendendo pela inconstitucionalidade em 185, ou seja, 6.1\%. Ver http://scdb.wustl.edu/ analysisCrosstabs.php?sid=1802-BLUEBIRD-9428. Acesso em: 6 abr. 2020.

13 O uso desse poder é controverso na teoria constitucional. Roznai e Brandes (2019), por exemplo, argumentam que emendas constitucionais que afetem a independência judicial deveriam estar sujeitas a um controle de constitucionalidade mais intenso. Por outro lado, da mesma forma que há uma tendência global à crescente aceitação de limites materiais ao poder de emenda (Roznai, 2013; Comissão de Veneza, 2016), parece haver uma tendência global entre os constitucionalistas de reconhecer que juízes deveriam ter, em princípio, esse poder, e que o texto constitucional deveria reconhecê-lo (Albert, Nakashidze e Olcay, 2019; para uma posição contrária, ver Albert, 2018; ver ainda Pereira, 2017, para uma discussão dos fundamentos teóricos por trás dessas diferentes posiçóes).

14 Ver, p.ex., Scotti, 2018, pp. 63-64; Roznai, 2013, pp. 690-694.

15 A taxa de emendamento de uma constituição é um dado relevante para fazer qualquer comparação, entre países, da frequência de declaraçôes de inconstitucionalidade de emendas como indicador de "ativismo". Se o núcleo essencial de uma constituição for alvo de mais tentativas de mudança, espera-se que, mantidas iguais outras variáveis, o tribunal constitucional também acabará declarando mais emendas inconstitucionais ao longo do tempo. Contudo, no caso brasileiro, não há uma relação direta entre o alto número de emendas e mudanças das estruturas e compromissos fundamentais da Constituiçáo. A maior parte das emendas lidam com aspectos periféricos do texto constitucional, ou adicionam a ele elementos novos, sem alterar sua estrutura básica ou os direitos e garantias que prevê (Arantes e Couto, 2019; ver também Benvindo, 2016).

16 ADIs 3854, 4014, 3855, 3105, 3128 e 3872.

17 ADIs 2356 e 2362.

18 ADIs 4425 e 4357.

19 ADI 5679.

20 ADIs 3395 e 3684.

21 ADIs 4310 e 4307.

22 Salgado e Chagas, 2019. Para uma análise e crítica geral do poder de decisão individual no STF, ver Arguelhes e Ribeiro, 2018.

\section{BIBLIOGRAFIA}

ALBERT, Richard; NAKASHIDZE, Malkhaz; \& OLCAY, Tarik. (2019), "The Formalist Resistance to Unconstitutional Constitutional Amendments". Hastings LJ, 70: 639-670.

ANTÍA, Florencia \& VAIRO, Daniela. (2019), "Politics and Justice in Uruguay: the power of the Supreme Court of Justice (1990-2018)". Revista Uruguaya de Ciencia Politica, 28(2): 61-86.

ARANTES, Rogério Bastos \& COUTO, Cláudio. (2006), "Constituição, governo e democracia no Brasil". Revista Brasileira de Ciências Sociais, 21, 61: 41-62. https://doi.org/10.1590/S010269092006000200003.

ARANTES, Rogério Bastos \& COUTO, Cláudio. (2008), "A constituição sem fim", in S. Praça \& S. Diniz (orgs.), Vinte anos de Constituição. São Paulo, Paulus.

ARANTES, Rogério Bastos \& COUTO, Cláudio. (2019), "1988-2018: Trinta anos de constitucionalização permanente", in: N. M. Filho \& A. P. Souza (orgs.). A Carta: para entender a Constituição brasileira. São Paulo, Todavia.

ARGUELHES, Diego Arguelhes \& HARTMANN, Ivar Alberto. (2017), “Timing Control without Docket Control: How Individual Justices Shape the Brazilian Supreme Court's Agenda”. Journal of Law and Courts, 5, 1: 105-140. 
ARGUELHES, Diego Werneck \& RIBEIRO, Leandro Molhano. (2018), “'The Court, it is I'? Individual judicial powers in the Brazilian Supreme Court and their implications for constitutional theory". Global Constitutionalism 7, 2: 236-262.

ARGUELHES, Diego Werneck \& SÜSSEKIND, Evandro Proença. (2018), "Judicialização antes da democratização? O Supremo Tribunal Federal e o destino da Emenda Constitucional das "Diretas Já””. Pensar Revista de Ciências Jurídicas, 23, 4: 1-16.

BENVINDO, Juliano Zaiden. (2016), "The Brazilian Constitutional Amendment Rate: A Culture of Change?" Int'l J. Const. L. Blog. http://www. iconnectblog.com/2016/08/the-brazilianconstitutional-amendment-rate-a-culture-ofchange/.

BENVINDO, Juliano Zaiden \& COSTA, Alexandre. (2014), "A quem interessa o controle concentrado de constitucionalidade? O descompasso entre teoria e prática na defesa dos direitos fundamentais". https://papers.ssrn.com/sol3/ papers.cfm?abstract_id=2509541.

DIMOULIS, Dimitri \& LUNARDI, Soraya Regina Gasparetto. (2008), "Definição da pauta no Supremo Tribunal Federal e (auto)criação do processo objetivo". Anais do XVII Congresso Nacional do Conpedi, Brasília, 4.357-4.377.

FALCÃO, Joaquim; HARTMANN, Ivar Alberto \& CHAVES, Vítor. (2014), 3 o Relatório Supremo em Números: O Supremo e o Tempo. $1^{\text {a }}$ edição, Rio de Janeiro, FGV Direito Rio.

GLEZER, Rubens. (2013), "Ativismo moderado no STF no controle das emendas constitucionais", in: D. Dimoulis et al.(org.), Resiliência constitucional: compromisso maximizador, consensualismo politico e desenvolvimento gradual. São Paulo, Direito GV.

KNIGHT, Jack. (2001), “Institutionalizing constitutional interpretation", in: J. Ferejohn, J. Rakove e J. Riley (orgs.), Constitutional culture and democratic rule. Cambridge University Press.

LASSANCE, Antonio. (2016), "A república provisória do Brasil." Boletim de Análise Politico-Institucional (IPEA), 10. http://repositorio.ipea.gov.br/ handle/11058/7652.

MENDES, Conrado Hübner. (2005), “Judicial Review of Constitutional Amendments in the
Brazilian Supreme Court". Florida Journal of International Law, 17, 3: 449-461.

MOHALLEM, Michael Freitas. (2011), "Immutable clauses and judicial review in India, Brazil and South Africa: expanding constitutional courts' authority". The International Journal of Human Rights, 15, 5: 65-786.

OLIVEIRA, Fabiana Luci. (2016), “Agenda suprema: interesses em disputa no controle de constitucionalidade das leis no Brasil". Revista Tempo Social, 28, 1: 105-133. https://doi. org/10.11606/0103-2070.ts.2016.106021

OLIVEIRA, Fabiana Luci. (2017), "Quando a corte se divide: coalizóes majoritárias mínimas no Supremo Tribunal Federal". Revista Direito e Práxis, 8, 3: 1863-1908. http://www.scielo. br/pdf/rdp/v8n3/2179-8966-rdp-8-3-1863.pdf

OLIVEIRA, Fabiana Luci. (2004), "O Supremo Tribunal Federal no processo de transição democrática: uma análise de conteúdo dos jornais Folha de S. Paulo e O Estado de S. Paulo". Rev. Sociol. Polit., 22: 101-118. https://doi.org/10.1590/ S0104-44782004000100009.

OLIVEIRA, Vanessa. (2005), "Judiciário e privatizaçôes no Brasil: existe uma judicialização da política?”. Dados, 48, 3: 559-587. https://doi.org/10.1590/ S0011-52582005000300004

PEREIRA, Thomaz. (2016), "Poder constituinte originário e constituinte exclusiva", in: A. R. do Vale \& Fábio Lima Quintas (orgs.), Estudos sobre a jurisdição constitucional. São Paulo, Almedina.

PEREIRA, Thomaz (2017). "Constituting the amendment power: a framework for comparative amendment law", In R. Albert, X. Contiades, A. Fotaidou (orgs.), The Foundations and Traditions of Constitutional Amendment, Hart Publishing.

PERTENCE, José Paulo Sepúlveda. (2003), “O controle de constitucionalidade das emendas constitucionais pelo STF: crônica de jurisprudência”. Revista Brasileira de Direito Público, 1, 1.

RIBEIRO, Leandro Molhano \& ARGUELHES, Diego Werneck. (2015), "O Conselho no Tribunal: Perfil quantitativo das açóes contra o $\mathrm{CNJ}$ junto ao STF”. Revista Direito e Práxis, 6, 3: 464-503. RIBEIRO, Leandro Molhano \& ARGUELHES, Diego Werneck. (2018), "Nem evolução, nem renascimento? Contingência e captura corporativa 
em três décadas de mandado de injunção". Revista de Informação Legislativa, 55, 219: 103-132.

RIBEIRO, Leandro Molhano \& ARGUELHES, Diego Werneck. (2019), "Contextos da judicialização da política: elementos para um novo mapa teórico". Revista Direito GV, 15, 2: 1-21.

ROZNAI, Yaniv. (2013), "Unconstitutional constitutional amendments—-the migration and success of a constitutional idea". The American Journal of Comparative Law, 61, 3: 657-720.

ROZNAI, Yaniv. (2017), Unconstitutional constitutional amendments: The limits of amendment powers. Oxford University Press.

ROZNAI, Yaniv \& BRANDES, Tamar. (2019), "Democratic Erosion, Populist Constitutionalism and the Unconstitutional Constitutional Amendment Doctrine". Disponível no SSRN: https://ssrn.com/abstract=3394412

ROZNAI, Yaniv \& KREUZ, Letícia Regina Camargo. (2018), "Conventionality control and Amendment 95/2016: a Brazilian case of unconstitutional constitutional amendment". Rev. Investig. Const. 5, 2: 35-56.

SABSAY, Daniel Alberto. (1999), "El control de constitucionalidad de la reforma constitucional en un fallo de la Corte Suprema de Justicia argentina". Anuario iberoamericano de justicia constitucional, 3: 427-460.

SALGADO, Desiree Eneida \& CHAGAS, Carolina Alves. (2019), "The Judicial Review of Constitutional Amendments in Brazil and the Super-Counter majoritarian Role of the Brazilian Supreme Court - The Case of the 'ADI 5017'”, in: R. Albert; C. Bernal \& J. Z. Benvindo (orgs.), Constitutional Change and Transformation in Latin America, Bloomsbury Publishing.
SCOTTI, Valentina Rita. (2018), "Constitutional amendments and constitutional core values: the Brazilian case in a comparative perspective". Revista de Investigaçöes Constitucionais, 5, 3: 59-76.

SOUZA, Celina. (2008), "Regras e contexto: as reformas da Constituição de 1988”. Dados, 51, 4: 791-823.

SÜSSEKIND, Evandro Proença. (2014), "Vontade do tribunal ou constituição generosa? Trazendo o constituinte para o debate sobre o controle de constitucionalidade preventivo". Coleção Jovem Jurista, FGV, 1: 11-62.

SÜSSEKIND, Evandro Proença. (2017), Arena ou jogador? Uma investigação sobre a judicializaçāo dos conflitos internos à Câmara dos Deputados por seus integrantes. 2017. Tese de mestrado. Universidade do Estado do Rio de Janeiro, Instituto de Estudos Sociais e Políticos, Rio de Janeiro.

TAYLOR, Matthew. (2007), "O judiciário e as políticas públicas no Brasil”. Dados, 50, 2: 229-257.

TAYLOR, Matthew \& DAROS, Luciano. (2008), "Os partidos dentro e fora do poder: a judicialização como resultado contingente da estratégia política”. Dados, 51, 4: 825-864.

TIEDE, Lydia. (2015), "The political determinants of judicial dissent: evidence from the Chilean Constitutional Tribunal". European Political Science Review, 8, 3: 377-403.

VIANNA, Luiz Werneck; BURGOS, Marcelo Baumann \& SALLES, Paula Martins. (2007), "Dezessete anos de judicialização da política". Tempo Soc [online], 19(2): 39-85.

VIEIRA, Oscar Vilhena \& BARBOSA, Ana Laura Pereira. (2018), "Do compromisso maximizador à resiliência constitucional”. Novos Estudos CEBRAP, 37, 3: 375-393. 


\section{O SUPREMO TRIBUNAL FEDERAL E A MUDANÇA CONSTITUCIONAL}

\author{
Fabiana Luci de Oliveira e Diego \\ Werneck Arguelhes
}

Palavras-chave: Supremo Tribunal Federal; Mudança constitucional; Controle de constitucionalidade; Emendas constitucionais; Judicialização.

Este artigo discute a mudança constitucional, no Brasil, a partir da formação de agenda e do processo decisório do Supremo Tribunal Federal em Açôes Diretas de Inconstitucionalidade (ADIs) contra emendas constitucionais. A metodologia adotada foi a análise de conteúdo das petiçôes iniciais e das decisôes (quando existentes) em 115 ADIs, ajuizadas no tribunal entre 1988 e 2018, visando responder a três questóes descritivas: 1) quais emendas foram questionadas, e quais aspectos dessas emendas foram contestados; 2) quais atores buscaram limitar e modular a mudança constitucional; 3) quais respostas o tribunal forneceu. Os resultados mostram que o Supremo tem participado de forma significativa no processo de mudança constitucional, interferindo na produção legislativa. Em $20 \%$ das vezes em que foi chamado a se posicionar, em ADIs, sobre emendas à Constituição, o Tribunal interferiu, suspendendo efeitos de dispositivos ou modulando as mudanças legislativas por meio da adoção de uma interpretação conforme a Constituição. Esses resultados apontam para um tribunal ativo no uso do poder de controle de emendas. Os dados também sugerem que as principais entidades beneficiadas por esse mecanismo de controle e pela reação do tribunal no período analisado foram as associaçôes profissionais de carreiras públicas da Justiça.

\section{SUPREME FEDERAL COURT AND CONSTITUTIONAL CHANGE}

\section{Fabiana Luci de Oliveira and Diego Werneck Arguelhes}

Key words: Brazilian Federal Supreme Court; Constitutional change; Judicial review; Constitutional amendments; Judicialization.

This paper discusses constitutional change in Brazil through the Supreme Federal Court's (STF) agenda and decision-making processes on abstract review lawsuits (Ações Diretas de Inconstitucionalidade). We analyze the content of initial petitions submittedby the parties, as well as existing decisions on these cases, in 115 lawsuits filed between 1988 and 2018 challenging constitutional amendments, in order to answer three descriptive questions: (i)which amendments were challenged before the STF, and which aspects of these amendments were disputed; (ii) which actors sought to limit and reshape constitutional change by challenging an amendment before the court; (iii) how the STF answered these challenges. The results show that the STF has been a relevant participant in processes of constitutional change, significantly interfering in the legislative output of amendments. The Court intervened in 20\% of the cases, either by directly suspending the effects of amendment provisions or by modulating the substance of legislative changes through a "saving construction" of the amendment's meaning. The data depicts the Court actively performing constitutional review of amendments, and it suggests that the most frequent beneficiaries of judicial intervention in these cases have been professional associations of civil servants.

\section{LA COUR SUPRÊME BRÉSILIENNE ET LE CHANGEMENT CONSTITUTIONNEL}

\author{
Fabiana Luci de Oliveira et Diego \\ Werneck Arguelhes
}

Mots-clés: Cour Suprême Fédérale du Brésil; changement constitutionnel; contrôle de constitutionnalité; amendements constitutionnels; judiciarisation.

Cet article examine le changement constitutionnel au Brésil à partir de la formation d'un agenda et du processus décisionnel de la Cour Suprême, et ce, dans les actions directes en inconstitutionnalité (ADI) contre les amendements constitutionnels. La méthodologie adoptée analyse le contenu des requêtes initiales et des décisions (lorsqu'elles existent) de 115 ADI déposées devant les tribunaux entre 1988 et 2018 , dans le but de répondre à trois questions descriptives: (i) quels amendements ont été remis en question et quels aspects de ces amendements ont été contestés?; (ii) quels acteurs ont cherché à limiter et à moduler les changements constitutionnels ?; (iii) et quelles ont été les réponses fournies par le tribunal ? Les résultats montrent que la Cour Suprême a participé de manière significative au processus de changement constitutionnel et interféré dans la production législative. Dans $20 \%$ des cas où elle a été appelée à se positionner dans les ADI sur des amendements constitutionnels, elle a suspendu des effets de dispositifs ou modulé les changements législatifs en adoptant une interprétation conforme à la Constitution. Ces résultats indiquent un tribunal actif dans l'utilisation du pouvoir de contrôle des modifications constitutionnelles. Les données suggèrent également que les principales entités bénéficiant de ce mécanisme de contrôle et de la réaction du tribunal au cours de la période analysée sont des associations professionnelles de fonctionnaires du judiciaire. 